JOURNAL OF INCLUSION PHENOMENA AND MACROCYCLIC CHEMISTRY (ISSN: 1388-3127) (eISSN: 1573-1111) 2014: pp. 1-9. (2014)

DOI: $10.1007 / \mathrm{s} 10847-014-0384-8$

\title{
Synthesis and recognition properties of $\alpha$-D-glucose-based
}

\section{fluorescent crown ethers incorporating an acridine unit}

\author{
Zsolt Rapi, ${ }^{1}$ Péter Bakó, ${ }^{1 *}$ György Keglevich, ${ }^{1}$ \\ Péter Baranyai, ${ }^{2}$ Miklós Kubinyi, ${ }^{2,3}$ Olívia Varga ${ }^{2}$
}

\footnotetext{
${ }^{1}$ Department of Organic Chemistry and Technology, Budapest University of Technology and Economics, PO Box 91, 1521 Budapest, Hungary, E-mail: pbako@mail.bme.hu

${ }^{2}$ Institute of Molecular Pharmacology, Research Centre for Natural Sciences, Hungarian Academy of Sciences, PO Box 17, H-1525 Budapest, Hungary

${ }^{3}$ Department of Physical Chemistry and Materials Science, Budapest University of Technology and Economics, PO Box 91, 1521 Budapest, Hungary
}

\begin{abstract}
Two new chiral glucopyranoside-based crown ethers incorporating acridine fluorescent signalling units, 15-membered ligand $\mathbf{1}$ and 21-membered ligand $\mathbf{2}$ were synthesized. Their complexation properties toward alkali and alkali earth metal ions, and their enantioselectivity towards chiral ammonium salts were studied by absorption and fluorescence spectroscopic experiments. Macrocycle 1 formed 1:1 complexes with all the metal ions selected and the stability constants were low $(\lg K<2.3)$. The cavity-size of 2 allowed only the complexaton of organic ammonium ions. Crown 2 showed chiral discrimination in case of all the four ammonium salts used as model guest compounds; the highest enantioselectivity $(\mathrm{K}(R) / \mathrm{K}(S) \sim 3)$ was observed for the enantiomers of phenylethyl ammonium (PEA) perchlorate. Ligand 2 forms much more stable complexes with metal ions; the highest stability constant was obtained for the $\mathrm{Ca}^{2+}$ complex $(\lg \mathrm{K}=6.15)$. The coordination of metal ions by ligand $\mathbf{2}$ was accompanied by marked fluorescence enhancement, whereas the binding of ammonium ions by the same species resulted in significant fluorescence quenching.
\end{abstract}

Keywords: Chiral crown ethers, carbohydrate-based crown ethers, fluorescence, complexation, enantiomeric recognition, photoinduced electron transfer (PET) 


\section{INTRODUCTION}

Recently, much research efforts have been devoted to the development of chiral fluorescent hosts, suitable for the discrimination of the two enantiomers of small chiral guests, as they can be used for the real-time monitoring of the formation/conversion of chiral reaction components. ${ }^{1-6}$ These synthetic receptors comprise a binding unit, a stereogenic center and a fluorophor signalling unit. Chiral fluorescent crown ethers form a promising class of such type synthetic receptors. In the examples reported so far, the crown ether either contains asymmetric $\mathrm{C}$ atoms, ${ }^{7-9}$ or it incorporates a BINOL group, ${ }^{10-13}$ the latter may also function as a chromophor/fluorophor unit. ${ }^{10-12}$

In the present work our aim was to synthesize a sugar-based fluorescent crown ether and to characterize its performance as a chiral molecular sensor by optical spectroscopic experiments. Macrocyclic compounds containing carbohydrate subunits have been prepared in a growing number. ${ }^{13-20}$ A few representatives showed significant asymmetric induction as chiral phase transfer catalysts in asymmetric reactions. ${ }^{21}$ Only a few sugar-based chiral crown compounds displayed an enantiomeric discrimination ability against chiral ammonium compounds in solutions. ${ }^{22}$ To the best of our knowledge, no sugar-based fluorogenic crown ether has been described that was found suitable for fluorescence studies.

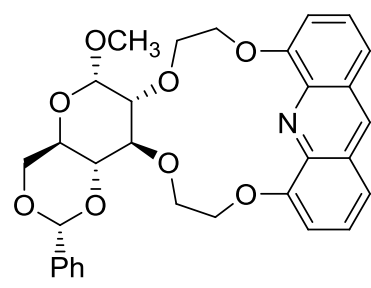

1

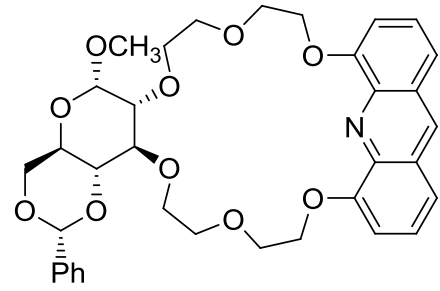

2

Figure 1. Structures of glucose-based fluorescent crown ethers studied

The two new sugar-based macrocycles - the 15-membered acridino crown $\mathbf{1}$, and its 21-membered analogue 2 - are shown in Fig. 1. We chose acridine as the fluorescent signalling group, since the acridino crown ethers described in a recent study $^{7}$ were found to exhibit significant changes in their fluorescence spectra upon the binding of ammonium ion 
guests. Besides, the incorporated acridine unit was expected to increase the selectivity of the complex formation, as it can contribute to the host-guest interaction via hydrogen bonding, $\pi$ $\pi$ stacking (in case of aromatic amine guests) and steric repulsion. ${ }^{23,24}$ Finally, macrocycles with a polycyclic aromatic unit (like acridine) incorporated are more rigid, improving their

selectivity. ${ }^{25,26}$ As some acridino-crown ethers were reported to be efficient fluoroionophores for the detection of various metal ions, ${ }^{27,28}$ the metal ion complexation of $\mathbf{1}$ and $\mathbf{2}$ have also been investigated in the present study.

\section{EXPERIMENTAL}

\section{General}

Melting points were taken on using a Büchi 510 apparatus and are uncorrected. Optical rotations were measured with a Perkin-Elmer 241 polarimeter at $20^{\circ} \mathrm{C} .{ }^{1} \mathrm{H}$ and ${ }^{13} \mathrm{C}$ NMR spectra were recorded on a Bruker 300 and a Bruker DRX-500 or a Varian Inova 500 instrument in $\mathrm{CDCl}_{3}$ with TMS as the internal standard or in DMSO-D 6 . The exact mass measurements were performed using a Q-TOF Premier mass spectrometer (Waters Corporation, 34 Maple St, Milford, MA, USA) in positive electrospray ionization mode. Analytical and preparative thin layer chromatography was performed on silica gel plates (60 GF-254, Merck), while column chromatography was carried out using 70-230 mesh silica gel (Merck). Chemicals were purchased from Aldrich Chem. Co.

UV-vis spectra were taken on a photodiode array Agilent 8453 spectrophotometer. Fluorescence spectra were recorded on an Edinburgh Instruments FLS920 spectrofluorimeter. Both the emission and excitation spectra were corrected by the software of the spectrometer. Quartz cuvettes with a path length of $1 \mathrm{~cm}$ were used. The concentrations of ligands were 20 $\mu \mathrm{M}$ in general, but $5 \mu \mathrm{M}$ when titrated with protonated naphthyl-ethyl amine (NEA).

\section{Preparation of 3-methoxy-2-nitrobenzoic acid (4)}

To 3-methoxybenzoic acid $3(40.0 \mathrm{~g}, 0.26 \mathrm{~mol})$ was added $65 \% \mathrm{HNO}_{3}(260 \mathrm{ml})$ under intensive stirring. Then, cc. $\mathrm{H}_{2} \mathrm{SO}_{4}(4 \mathrm{ml})$ was added dropwise and the well-stirred mixture was heated to $45^{\circ} \mathrm{C}$. After the reaction started, the temperature was kept at $40^{\circ} \mathrm{C}$ for $4 \mathrm{~h}$. Water $(300 \mathrm{ml})$ was added, and the mixture was filtrated. The precipitate was washed twice with hot anhydrous EtOH $(2 \times 70 \mathrm{ml})$ and the residue was recrystallized from $\mathrm{EtOH}(150 \mathrm{ml})$ to 
give 4 (10.4 g, $21 \%$ ) as yellow crystals. mp: $248-250^{\circ} \mathrm{C}$; (lit. ${ }^{29} \mathrm{mp}: 249-250^{\circ} \mathrm{C}$ ) ${ }^{1} \mathrm{H}$ NMR (DMSO-D $6,500 \mathrm{MHz}), \delta$ (ppm) 13.89 (br s, COOH), 7.65 (t, $J=8 \mathrm{~Hz}, 1 \mathrm{H}), 7.59$ (d, $J=8 \mathrm{~Hz}$, 1H), 7.55 (d, $J=8 \mathrm{~Hz}, 1 \mathrm{H}), 3.91$ (s, 3H). ${ }^{13} \mathrm{C}$ NMR (DMSO-D, $\left.75 \mathrm{MHz}\right), \delta$ (ppm) 164.06, $150.15,131.34,124.03,121.79,121.57,117.78,56.88 . \mathrm{MS}(\mathrm{m} / \mathrm{z}) 197.0\left[\mathrm{M}^{+}\right]$.

\section{Preparation of 2-amino-3-methoxybenzoic acid (5)}

3-Methoxy-2-nitrobenzoic acid 4 (24.8 g, $0.13 \mathrm{~mol}$ ) was dissolved in $\mathrm{MeOH}$ (300 ml) and was catalytically hydrogenated in the presence of $2.5 \mathrm{~g}$ of Pd/C (SQ-6) at room temperature and at 10 bar for 15 minutes. Then the mixture was filtered trough Celite, and the solvent was evaporated to give compound $5(20.7 \mathrm{~g}, 98 \%)$ as a yellow solid material. mp: $173-174^{\circ} \mathrm{C}$; (lit. ${ }^{30} \mathrm{mp}: 172-175^{\circ} \mathrm{C}$ ); ${ }^{1} \mathrm{H}$ NMR (DMSO-D $6,500 \mathrm{MHz}$ ), $\delta$ (ppm) 8.32 (br s $3 \mathrm{H}, \mathrm{NH}_{2}$, $\mathrm{COOH}), 7.32$ (d, $J=7.8 \mathrm{~Hz}, 1 \mathrm{H}), 6.95$ (d, $J=7.8 \mathrm{~Hz}, 1 \mathrm{H}), 6.49$ (t, $J=7.8 \mathrm{~Hz}, 1 \mathrm{H}), 3.80$ (s, $3 \mathrm{H}) .{ }^{13} \mathrm{C}$ NMR (DMSO-D, $\left.75 \mathrm{MHz}\right), \delta$ (ppm) 169.55, 145.57, 141.79, 122.37, 113.73, 113.28, 109.55, 55.52. MS (m/z) 167.1 $\left[\mathrm{M}^{+}\right]$.

\section{Preparation of $N$-(2-methoxyphenyl)-3-methoxyanthranilic acid (7)}

2-Amino-3-methoxybenzoic acid 5 (20.7 g, $0.12 \mathrm{~mol}$ ) and 2-bromoanisole 6 (16.8 ml, 0.14 mol) were dissolved in anhydrous 2-ethoxyethanol $(80 \mathrm{ml})$, then powdered anhydrous $\mathrm{K}_{2} \mathrm{CO}_{3}$ (16.6 g, $0.12 \mathrm{~mol})$, copper powder $(0.18 \mathrm{~g}, 2.8 \mathrm{mmol})$ and copper (I) oxide $(0.18 \mathrm{~g}, 1.6 \mathrm{mmol})$ were added, and the mixture was stirred vigorously under argon for $10 \mathrm{~min}$, then refluxed for ca. $150 \mathrm{~h}$ until the starting material disappeared (TLC). The solvent was evaporated and the residue was taken up in a mixture of $600 \mathrm{ml}$ diethylether and $600 \mathrm{ml} 1 \%$ aqueous $\mathrm{NaOH}$. The aqueous phase was extracted with diethylether $(2 \times 200 \mathrm{ml})$, and the combined organic phase was discarded. Charcoal (3.0 g) was added to the aqueous phase and the suspension was boiled for $15 \mathrm{~min}$. Then the mixture was filtrated and the filtrate cooled to $0^{\circ} \mathrm{C}$ in an ice-water bath. Glacial acetic acid ( $c a .35 \mathrm{ml})$, was added dropwise $(\mathrm{pH}$ 5) to precipitate the crude product, which was filtered, dried $\left(\mathrm{Na}_{2} \mathrm{SO}_{4}\right)$ and purified by flash chromatography (eluent $\mathrm{CH}_{2} \mathrm{Cl}_{2}$ ) to give product 7 (24.7 g, 73\%). mp 175-176 ${ }^{\circ}$; (lit. ${ }^{31} \mathrm{mp} 176-177^{\circ} \mathrm{C}$ ); ${ }^{1} \mathrm{H} \mathrm{NMR}$ (DMSO-D $6,500 \mathrm{MHz}$ ), $\delta$ (ppm) 13.12 (br s, $\mathrm{COOH}$ ), 8.52 (br s, NH $\left.\mathrm{NH}_{2}\right), 7.51$ (d, $J=8 \mathrm{~Hz}, 1 \mathrm{H}$ ), $7.26(\mathrm{~d}, J=8 \mathrm{~Hz}, 1 \mathrm{H}), 7.09(\mathrm{t}, J=8 \mathrm{~Hz}, 1 \mathrm{H}), 6.92(\mathrm{~d}, J=8 \mathrm{~Hz}, 1 \mathrm{H}), 6.77(\mathrm{t}, J=7.5 \mathrm{~Hz}, 1 \mathrm{H})$, $6.72(\mathrm{t}, J=7.5 \mathrm{~Hz}, 1 \mathrm{H}), 6.29(\mathrm{~d}, J=7.5 \mathrm{~Hz}, 1 \mathrm{H}), 3.85(\mathrm{~s}, 3 \mathrm{H}), 3.70(\mathrm{~s}, 3 \mathrm{H}) .{ }^{13} \mathrm{C} \mathrm{NMR}$ 
(DMSO-D 6,75 MHz), $\delta(\mathrm{ppm})$ 168.01, 154.77, 149.43, 134.26, 132.10, 126.64, 123.70, $122.41,120.91,116.38,115.86,110.64,56.28,56.01 . \mathrm{MS}(\mathrm{m} / \mathrm{z}) 273.1\left[\mathrm{M}^{+}\right]$.

\section{Preparation of 4,5-dimethoxyacridin-9(10H)-one (8)}

$N$-(2-Methoxyphenyl)-3-methoxyanthranilic acid 7 (5.7 g, $21.0 \mathrm{mmol})$ was dissolved in cc $\mathrm{H}_{2} \mathrm{SO}_{4}(40 \mathrm{ml})$ and the mixture was stirred at $100{ }^{\circ} \mathrm{C}$ for $1 \mathrm{~h}$. The warm mixture was slowly poured into $200 \mathrm{ml}$ water, and the resulting slurry was stirred for 30 minutes. The slurry was cooled to $0^{\circ} \mathrm{C}$ in an ice-water bath and kept at this temperature for 2 hours. The precipitate was filtered, washed with water, then dried $\left(\mathrm{Na}_{2} \mathrm{SO}_{4}\right)$. The crude product was recrystallized from glacial acetic acid to give product 8 (3.8 g, 72\%). mp $276-278^{\circ} \mathrm{C}$ (lit. ${ }^{31} \mathrm{mp} 277-278^{\circ} \mathrm{C}$ );

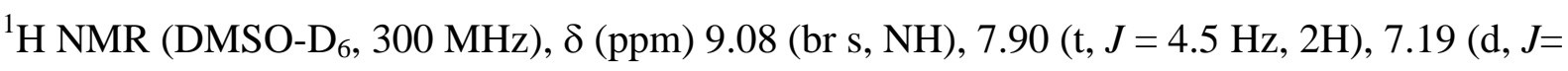
$4.5 \mathrm{~Hz}, 4 \mathrm{H}), 4.09$ (s, 6H). ${ }^{13} \mathrm{C}$ NMR (DMSO-D $\left.6,75 \mathrm{MHz}\right), \delta$ (ppm) 178.10, 147.58, 131.30, 122.05, 120.92, 118.49, 111.44, 56.18. MS (m/z) $255.1\left[\mathrm{M}^{+}\right]$.

\section{Preparation of 4,5-dihydroxyacridin-9(10H)-one (9)}

In a three-necked round-bottomed flask equipped with a thermomether and a distillation head pyridinium chloride $(95.0 \mathrm{~g}, 0.82 \mathrm{~mol})$ was placed and melted by heating to $160^{\circ} \mathrm{C}$, then 4,5 dimethoxyacridin-9(10H)-one 8 (7.5 g, $29.4 \mathrm{mmol})$ was added, and the mixture was stirred at $220^{\circ} \mathrm{C}$ for 2 hours. The reaction mixture was poured into $1000 \mathrm{ml}$ ice-cold water and was stirred at $0^{\circ} \mathrm{C}$ for 1 hour. The precipitate was filtered off, washed with water $(3 \times 50 \mathrm{ml})$, dried $\left(\mathrm{Na}_{2} \mathrm{SO}_{4}\right)$ and recrystallized from DMF to give product $9(3.7 \mathrm{~g}, 55 \%)$. Mp. $>340^{\circ} \mathrm{C}$; (lit. ${ }^{31}$ mp: $>360^{\circ} \mathrm{C}$ ); ${ }^{1} \mathrm{H}$ NMR (DMSO-D $\left.6,300 \mathrm{MHz}\right), \delta$ (ppm) 10.87 (br s, $\left.2 \mathrm{OH}\right), 9.05$ (br s, NH), $7.68(\mathrm{~d}, J=5.1 \mathrm{~Hz}, 2 \mathrm{H}), 7.18(\mathrm{~d}, J=6.6 \mathrm{~Hz}, 2 \mathrm{H}), 7.09$ (t, $J=7.8 \mathrm{~Hz}, 2 \mathrm{H}) .{ }^{13} \mathrm{C} \mathrm{NMR}$ (DMSO-D 6 , 75 MHz), $\delta$ (ppm) 176.73, 145.48, 130.39, 121.32, 120.98, 115.90, 115.59. MS $(\mathrm{m} / \mathrm{z}) 227.1\left[\mathrm{M}^{+}\right]$.

\section{Preparation of 4,5-dihydroxyacridine (10)}

4,5-Dihydroxy-acridine-9-(10H)-one 9 (1.0 g, $4.4 \mathrm{mmol})$ was dissolved in boiling $n$-propanol $(50 \mathrm{ml})$ and the solution was allowed to cool to $90^{\circ} \mathrm{C}$. Sodium $(3.0 \mathrm{~g}, 130.0 \mathrm{mmol})$ was added to the mixture in small portions under Ar gas. The solution was stirred at $90^{\circ} \mathrm{C}$ for 1 hour, 
then was allowed to cool to room temperature and water $(10 \mathrm{ml})$ was added dropwise. Calculated amount of $10 \%$ aq. $\mathrm{HCl}$ was added, and the $\mathrm{pH}$ was set to 7-8 using solid $\mathrm{NaHCO}_{3}$. The precipitate was filtered off, and crystallized from aqueous ethanol to give product $\mathbf{1 0}(0.35 \mathrm{~g}, 38 \%)$.

${ }^{1} \mathrm{H} \mathrm{NMR}\left(\mathrm{CDCl}_{3}-\mathrm{CD}_{3} \mathrm{OD}, 300 \mathrm{MHz}\right), \delta(\mathrm{ppm}): 8.77$ (s, 1H), 7.58-7.57 (m, 1H), 7.54 (dd, $J=$ $8.4 \mathrm{~Hz}, 0.9 \mathrm{~Hz}, 2 \mathrm{H}), 7.45$ (dd, $J=8.4 \mathrm{~Hz}, 7.2 \mathrm{~Hz}, 2 \mathrm{H}), 7.15(\mathrm{dd}, J=7.2 \mathrm{~Hz}, 0.9 \mathrm{~Hz}, 2 \mathrm{H})$,

${ }^{13} \mathrm{C}$ NMR $\left(\mathrm{CDCl}_{3}-\mathrm{CD}_{3} \mathrm{OD}, 75 \mathrm{MHz}\right), \delta(\mathrm{ppm})$ 153.15, 139.51, 136.10, 128.16, 127.39, 118.79, 109.77. MS (m/z) $211.1\left[\mathrm{M}^{+}\right]$.

\section{Preparation of Crown ether 1}

To a solution of 4,5-dihydroxyacridin-9(10H)-one 9 (1.0 g, $4.4 \mathrm{mmol})$ in anhydrous DMF (50 $\mathrm{ml})$, powdered anhydrous $\mathrm{Na}_{2} \mathrm{CO}_{3}(1.9 \mathrm{~g}, 17.6 \mathrm{mmol})$ was added, and the mixture was stirred under argon for $10 \mathrm{~min}$. Then glucose derivative $11(3.0 \mathrm{~g}, 4.4 \mathrm{mmol})$ in dry DMF $(20 \mathrm{ml})$ was added. The mixture was stirred at $60^{\circ} \mathrm{C}$ for $50 \mathrm{~h}$, then the solvent was removed. The residue (12) was dissolved in boiling $n$-propanol $(55 \mathrm{ml})$, and metal sodium ( $3.5 \mathrm{~g}, 0.15 \mathrm{~mol})$ was added under argon gas in small portions. The mixture was refluxed for $30 \mathrm{~min}$, and after cooling to $25^{\circ} \mathrm{C}$, water $(15 \mathrm{ml})$ and $10 \%$ aqueous $\mathrm{HCl}(50 \mathrm{ml})$ were added, then the $\mathrm{pH}$ was set to 7-8 with solid $\mathrm{NaHCO}_{3}$. The mixture was poured into $\mathrm{CH}_{2} \mathrm{Cl}_{2}(50 \mathrm{ml})$, the phases were separated, and the aqueous phase was extracted with $\mathrm{CH}_{2} \mathrm{Cl}_{2}(3 \times 40 \mathrm{ml})$. The combined organic phase was dried $\left(\mathrm{Na}_{2} \mathrm{SO}_{4}\right)$ and after removal of the solvent, the residue was purified by column cromatography ( silica gel, eluent $\mathrm{CHCl}_{3}$ ) to give crown ether $\mathbf{1}(1.1 \mathrm{~g}, 42 \%)$ as a yellow solid. Decomp. $>90^{\circ} \mathrm{C} .[\alpha]_{\mathrm{D}}^{20}=-23\left(c=1, \mathrm{CHCl}_{3}\right) ;{ }^{1} \mathrm{H} \mathrm{NMR}\left(\mathrm{CDCl}_{3}, 300 \mathrm{MHz}\right), \delta$ (ppm) 9.68 (s, 1H), 8.08 (dd, $J=7.2 \mathrm{~Hz}, 2.1 \mathrm{~Hz}, 1 \mathrm{H}), 8.05$ (dd, $J=7.5 \mathrm{~Hz}, 2.1 \mathrm{~Hz}, 1 \mathrm{H}), 7.48$ $(\mathrm{dd}, J=7.5 \mathrm{~Hz}, 1.8 \mathrm{~Hz}, 2 \mathrm{H}), 7.43-7.37(\mathrm{~m}, 3 \mathrm{H}), 7.20-7.08(\mathrm{~m}, 4 \mathrm{H}), 5.58(\mathrm{~s}, 1 \mathrm{H}), 5.01$ (d, $J=$ $3.6 \mathrm{~Hz}, 1 \mathrm{H}), 4.44-4.28(\mathrm{~m}, 6 \mathrm{H}), 4.14-4.06(\mathrm{~m}, 1 \mathrm{H}), 4.04-3.99(\mathrm{~m}, 1 \mathrm{H}), 3.97(\mathrm{~d}, J=9 \mathrm{~Hz}, 1 \mathrm{H})$, $3.90(\mathrm{dd}, J=8.4 \mathrm{~Hz}, 2.7 \mathrm{~Hz}, 1 \mathrm{H}), 3.86(\mathrm{dd}, J=9.6 \mathrm{~Hz}, 3.9 \mathrm{~Hz}, 1 \mathrm{H}), 3.78(\mathrm{~d}, J=10.2 \mathrm{~Hz}, 1 \mathrm{H})$, 3.74-3.64 (m, 2H), $3.48(\mathrm{~s}, 3 \mathrm{H}) .{ }^{13} \mathrm{C} \mathrm{NMR}\left(\mathrm{CDCl}_{3}-\mathrm{CD}_{3} \mathrm{OD}, 75 \mathrm{MHz}\right), \delta(\mathrm{ppm})$ 155.14, $155.10,141.25,141.11,137.27,135.29,129.13,128.34,128.15,127.98,127.88,127.74$, $126.03,119.60,119.54,107.84,107.26,101.48,97.33,83.20,78.93,71.79,69.89,69.45$, 69.04, 67.70, 62.03, 55.29. MS (m/z) $[\mathrm{M}+\mathrm{H}]^{+}$546.3, $[\mathrm{M}+\mathrm{Na}]^{+}$568.2; HRMS calcd for $\mathrm{C}_{31} \mathrm{H}_{31} \mathrm{NO}_{8}:$ 545.2050. Found 545.2052. 


\section{Preparation of crown ether 2}

To the solution of glucose-based bisiodo derivative $\mathbf{1 3}(1.4,2.0 \mathrm{mmol})$ in dry DMF $(40 \mathrm{ml})$ were added 4,5-dihydroxy-acridine (10) $(0.44 \mathrm{~g}, 2.0 \mathrm{mmol})$ and dry powdered $\mathrm{K}_{2} \mathrm{CO}_{3}(0.28 \mathrm{~g}$, $2.0 \mathrm{mmol}$ ) under argon. The reaction mixture was stirred at $70^{\circ} \mathrm{C}$ for $60 \mathrm{~h}$. The precipate was filtered and the filtrate was concentrated in vacuo. The residue was taken up in $\mathrm{CHCl}_{3}$, after filtration dried $\left(\mathrm{MgSO}_{4}\right)$ and concentrated again. Column chromatography of the residue (on silica gel using $\mathrm{CHCl}_{3}-\mathrm{CH}_{3} \mathrm{OH}$ 100:0 $\rightarrow$ 100:6 as the eluent) afforded compound 2 (0.85 g, $67 \%)$ as a yellow-brown solid. Decomp. $>75^{\circ} \mathrm{C} ;[\alpha]_{\mathrm{D}}^{20}=+24.8\left(c=1, \mathrm{CHCl}_{3}\right)$

${ }^{1} \mathrm{H} \mathrm{NMR}\left(\mathrm{CDCl}_{3}, 500 \mathrm{MHz}\right), \delta(\mathrm{ppm}): 8.66(\mathrm{~s}, 1 \mathrm{H}), 7.55(\mathrm{~d}, J=8.5 \mathrm{~Hz}, 2 \mathrm{H}), 7.47(\mathrm{dd}, J=7.5$ $\mathrm{Hz}, 2 \mathrm{~Hz}, 2 \mathrm{H}), 7.42$ (ddd, $J=7.5 \mathrm{~Hz}, 5 \mathrm{~Hz}, 2 \mathrm{~Hz}, 2 \mathrm{H}), 7.38-7.33(\mathrm{~m}, 3 \mathrm{H}), 6.98$ (t, $J=7.5 \mathrm{~Hz}$, 2H), $5.48(\mathrm{~s}, 1 \mathrm{H}), 4.84(\mathrm{~d}, J=4 \mathrm{~Hz}, 1 \mathrm{H}), 4.51-4.34(\mathrm{~m}, 5 \mathrm{H}), 4.27-4.11(\mathrm{~m}, 6 \mathrm{H}), 4.10-4.03(\mathrm{~m}$, $2 \mathrm{H}), 4.02-3.97(\mathrm{~m}, 1 \mathrm{H}), 3.95-3.82(\mathrm{~m}, 4 \mathrm{H}), 3.85-3.74(\mathrm{~m}, 1 \mathrm{H}), 3.66(\mathrm{t}, J=10 \mathrm{~Hz}, 1 \mathrm{H}), 3.52(\mathrm{t}$, $J=9.5 \mathrm{~Hz}, 1 \mathrm{H}), 3.48(\mathrm{dd}, J=9.5 \mathrm{~Hz}, 4 \mathrm{~Hz}, 1 \mathrm{H}), 3.41(\mathrm{~s}, 3 \mathrm{H}) .{ }^{13} \mathrm{C} \mathrm{NMR}\left(\mathrm{CDCl}_{3}-\mathrm{CD}_{3} \mathrm{OD}, 75\right.$ $\mathrm{MHz}), \delta(\mathrm{ppm}) 155.06,155.04,141.18,141.05,137.48,135.07,128.86,128.18,127.93$, 127.84, 126.06, 119.86, 119.76, 107.75, 107.21, 101.22, 99.1, 82.02, 79.75, 79.39, 73.02, $72.34,71.90,71.45,69.93,69.68,69.16,69.08,68.93,62.25,55.13 . \mathrm{MS}(\mathrm{m} / \mathrm{z})[\mathrm{M}+\mathrm{H}]^{+}$634.1; $[\mathrm{M}+\mathrm{Na}]^{+}$656.1; $[\mathrm{M}+\mathrm{K}]^{+}$672.1; HRMS calcd for $\mathrm{C}_{35} \mathrm{H}_{39} \mathrm{NO}_{10}$ : 633.2574. Found 633.2571.

\section{RESULTS AND DISCUSSION}

\section{Synthesis}

Key intermediate of the synthesis is 4,5-dihydroxyacridine 10, that was prepared in a 6-step reaction sequence (Scheme 1). Compound $\mathbf{1 0}$ has been described, but the synthesis was modified and the spectral characterization was completed by us. 


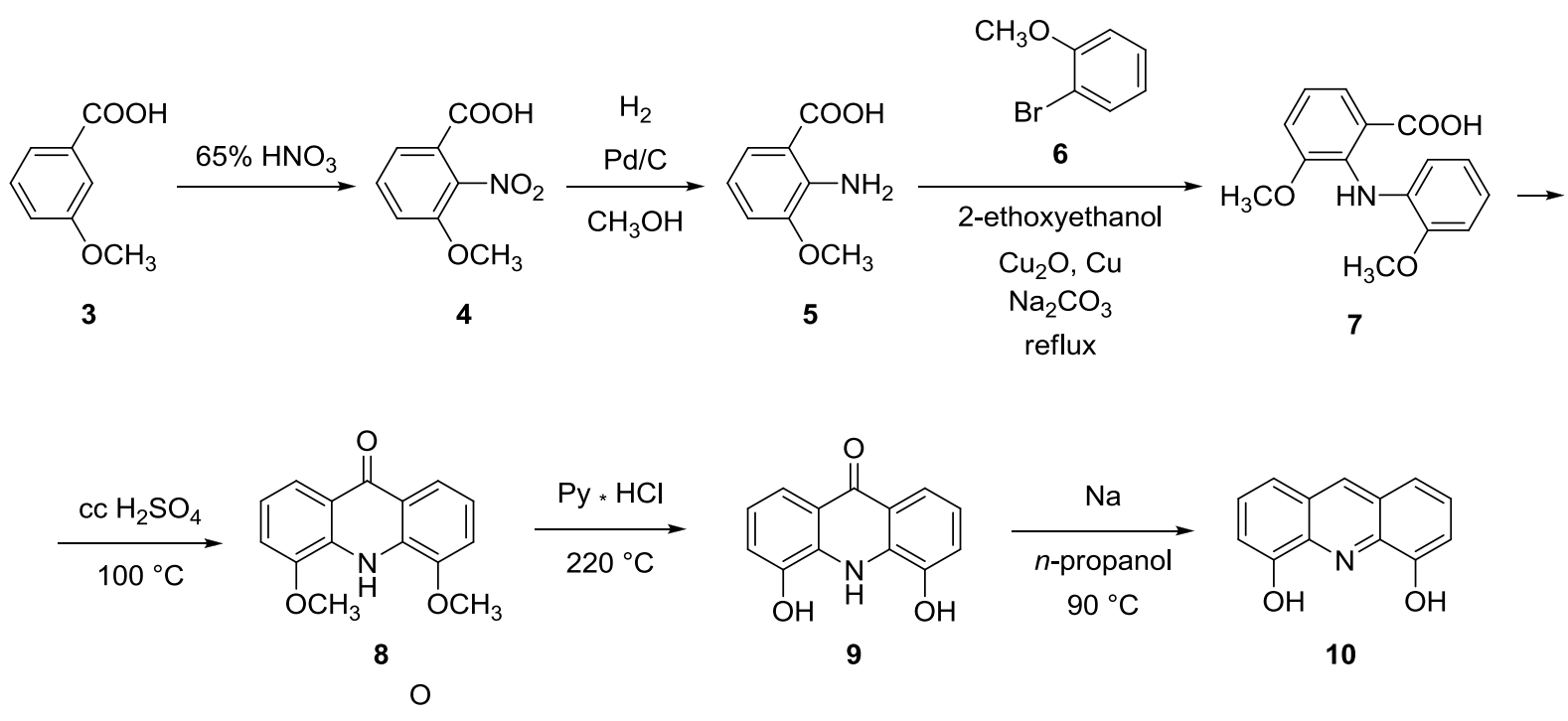

Scheme 1. Preparation of 4,5-dihydroxyacridine (10)

In the nitration of 3-methoxybenzoic acid (3) with nitrous acid 3-methoxy-2nitrobenzoic acid (4) was a minor component that could be separated from the mixture on the basis of its poorer solubility in a modest yield. ${ }^{29}$ Catalytic hydrogenation of nitro compound 4 using $\mathrm{Pd} / \mathrm{C}$ at $25^{\circ} \mathrm{C}$ a slight pressure furnished amine 5 in almost a quantitative yield. The 2amino-3-methoxybenzoic acid (5) was reacted with $o$-bromoanisol (6) in the presence of potassium carbonate, copper powder and copper(I) oxide heated in dry 2-ethoxyethanol to give a diarylamine derivative 7 described earlier $^{31}$ in a better yield of $73 \%$. The latter acid (7) was then converted to dimethoxyacridone 8 by intramolecular cyclization using conc. $\mathrm{H}_{2} \mathrm{SO}_{4}$ (without polyphosphoric acid) at $100^{\circ} \mathrm{C}$. Our method represents a modified synthesis. Cleavage of the $O$-methyl group using pyridinium chloride at elevated temperature in melt afforded 4,5-dihydroxiacridin-9(10H)-one 9 in a yield of 55\%. ${ }^{31}$ This intermediate (9) was already suitable for ring closure with glucose-based ditosylate 11. Our original goal was the synthesis and spectral characterization of macrocycles acridonon $\mathbf{1 2}$ and acridine $\mathbf{1}$. It became clear only in a later stage that compound $\mathbf{1 2}$ was not suitable for our study as a consequence of its poor solubility. Acridine $\mathbf{1 0}$ was formed in the reaction of compound $\mathbf{9}$ with sodium in boiling $n$-propanol in a yield of $38 \%$. The synthesis of chiral acridine-15-crown-5 ether (1) fused with the sugar ring of methyl-4,6- $O$-benzylidene- $\alpha$-D-glucopyranoside is shown in Scheme 2. 


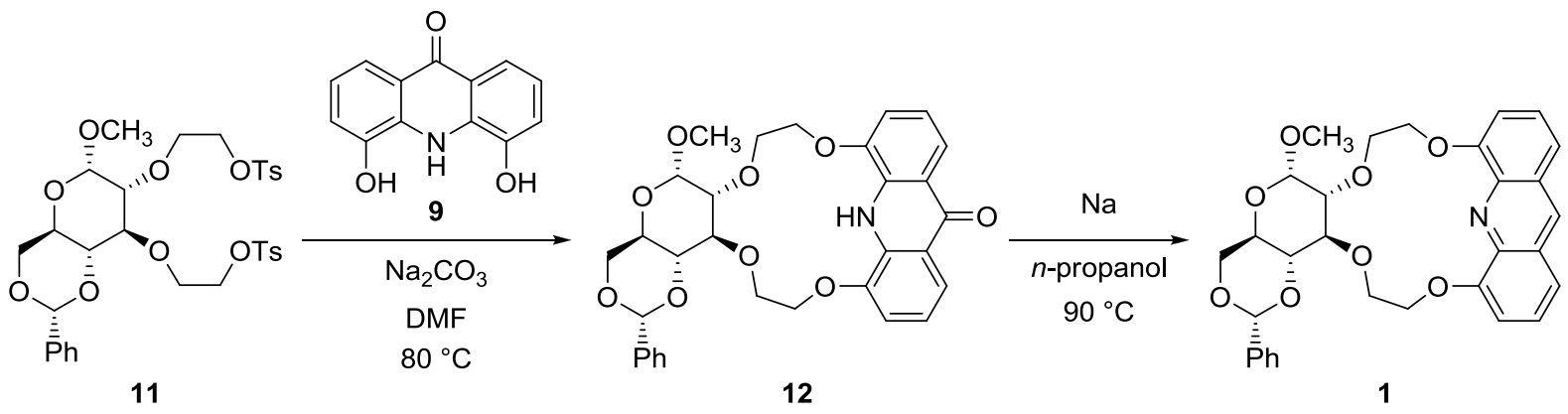

Scheme 2. Preparation of acridone macrocycle (12) and chiral sensor with an acridine unit (1)

The chiral macrocycle 12 containing the acridinone ring system was prepared by the condensation of glucose-based diolditosylate 11 and 4,5-dihydroxyacridinone 9 at $70^{\circ} \mathrm{C}$ in dry DMF in the presence of sodium carbonate (Scheme 2). Glucose-based ditosylate derivative 11 was prepared according to our previously reported method. ${ }^{32}$ Due to the low solubility of acridinone 12 it could not be prepared in a pure form. For this, crude $\mathbf{1 2}$ was used in the next step. The reduction of the carbonyl group was performed on the basis of an analogy from the literature $^{31}$ using sodium in boiling $n$-propanol. The overall yield of the two steps was $42 \%$ for 1. The analogous chiral sensor 2 with a larger ring size was prepared as shown in Scheme 3 .

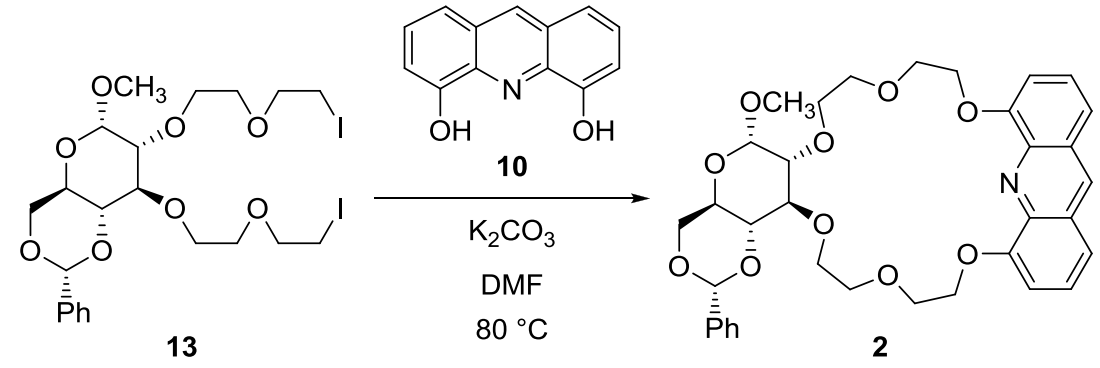

Scheme 3. Preparation of chiral sensor crown ether 2

The 21-membered glucose-based macrocycle 2 was prepared by the condensation of chiral bisiodo compound 13 and acridine-4,5-diol 10 at $80^{\circ} \mathrm{C}$ in the presence of $\mathrm{K}_{2} \mathrm{CO}_{3}$ in DMF. After a reaction time of $60 \mathrm{~h}$, macrocycle 2 was obtained in a yield of 67\%. Bisiodo intermediate 13 was prepared according to our previously reported method. ${ }^{18}$

In the course of the synthesis of acridine ligands $\mathbf{1}$ and $\mathbf{2}$, the progress of the reaction was monitored by thin layer chromatography (TLC) and a very intense blue fluorescent spot 
appeared on the silica gel TLC plates. It is worth mentioning that the two newly prepared crown ethers have different direction of the optical rotation. Crown compound $\mathbf{1}$ may be regarded to have an ,anomalous” optical rotation, as the rotation of the $\alpha$-D-glucopyranosidebased macrocycles, in most cases, have had a positive sign.

In the following stage, the complexation of alkali and alkali metal ions, as well as chiral amines (in the form of perchlorate salts) was studied in acetonitrile, by measuring the variations of the absorption and fluorescence spectra of the $10^{-5} \mathrm{M}$ solutions of the crown ethers upon the addition of the guest ions in different concentrations. In general, the fluorescence spectra were found much more sensitive to the concentration of the added guests than the absorption spectra. The stoichiometries and stability constants of complexes were determined from the fluorescence spectra by global nonlinear regression analysis, using the least-square method approximation.

\section{Metal ion complexation}

Significant changes in the spectra of the 15-membered crown 1 were observed only when the salts had been added in large $\left(\sim 10^{1}-10^{3}\right.$-fold $)$ excesses. As is illustrated in Fig. 2, the binding of the metal ions was accompanied by red shifts and distortion of the absorption and fluorescence bands, the fluorescence intensities showed only minor changes. The relatively largest shifts were observed in the presence of $\mathrm{Mg}^{2+}$ and $\mathrm{Ca}^{2+}$ ions. A global fitting of the fluorescence spectra proved the 1:1 stoichiometry of all the complexes formed, the association constants were found low $\left(<200 \mathrm{M}^{-1}\right.$, see Table 1$)$.

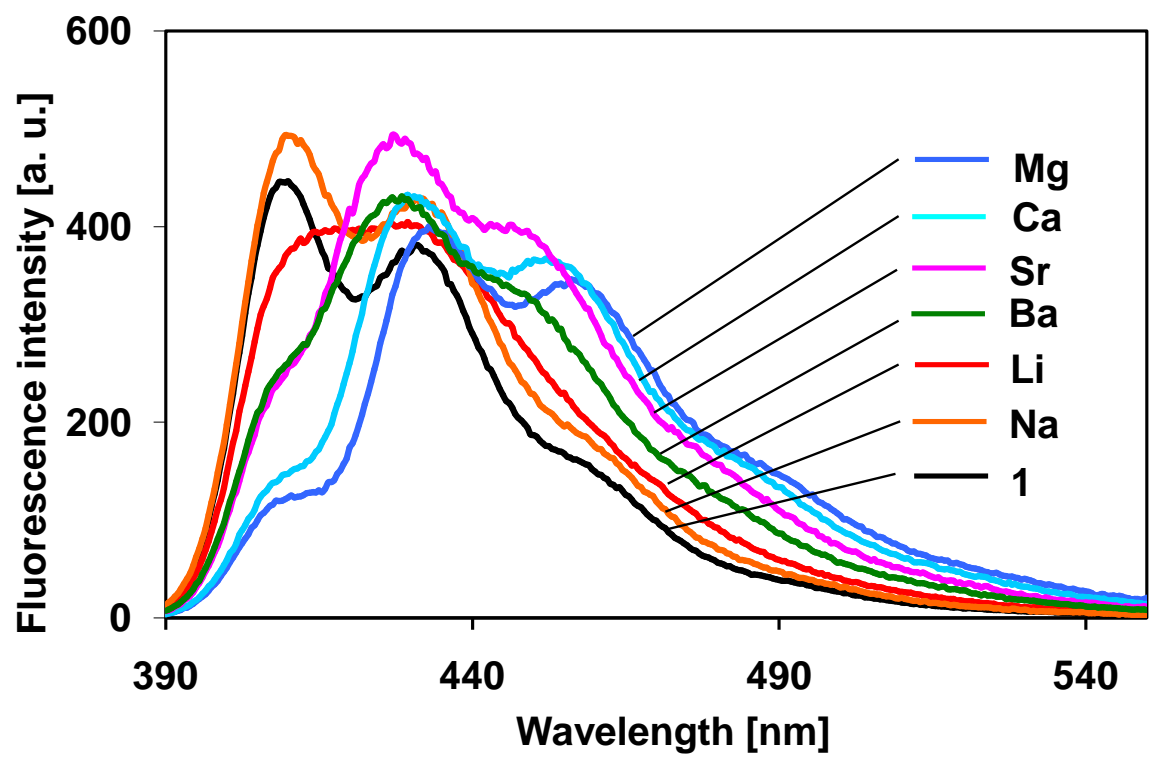


Fig. 2. Fluorescence spectra of $\mathbf{1}$ in the presence of metal ions. $[\mathbf{1}]_{0}=1 \times 10^{-5} \mathrm{M}$,

$$
\left[\mathrm{Me}^{\mathrm{n}+}\right]_{0}=1.6 \times 10^{-2} \mathrm{M}, \lambda_{\mathrm{ex}}=378 \mathrm{~nm} \text {. }
$$

Table 1. Stability constants for the metal ion complexes of ligands $\mathbf{1}$ and $\mathbf{2}$.

\begin{tabular}{ccc}
\hline & \multicolumn{2}{c}{$\lg$} \\
& \multicolumn{1}{c}{$\left(\mathrm{K} \mathrm{in}^{-1}\right)$} \\
\hline & $1.49 \pm 0.11$ & $\mathbf{2}$ \\
\hline $\mathrm{Li}$ & n.r. $^{\mathrm{a}}$ & $5.10 \pm 0.02$ \\
$\mathrm{Na}$ & $2.23 \pm 0.02$ & $4.37 \pm 0.04$ \\
$\mathrm{Mg}$ & $2.26 \pm 0.02$ & $6.15 \pm 0.12$ \\
$\mathrm{Ca}$ & $2.12 \pm 0.05$ & $6.09 \pm 0.07$ \\
$\mathrm{Sr}$ & $1.85 \pm 0.03$ & $\sim 6.7\left(\operatorname{lgK}_{1}\right)^{\mathrm{b}}$ \\
$\mathrm{Ba}$ & & $\sim 5.4\left(\operatorname{lgK}_{2}\right)$ \\
\hline
\end{tabular}

${ }^{a}$ no reaction

${ }^{\mathrm{b}} \mathrm{K}_{1}$ and $\mathrm{K}_{2}$ are the equilibrium constants for the reactions

$\mathrm{Ba}^{2+}+\mathbf{2} \rightleftharpoons[\mathrm{Ba} \cdot 2]^{2+}$ and $[\mathrm{Ba} \cdot 2]^{2+}+\mathbf{2} \rightleftharpoons\left[\mathrm{Ba} \cdot 2_{2}\right]^{2+}$, respectively.

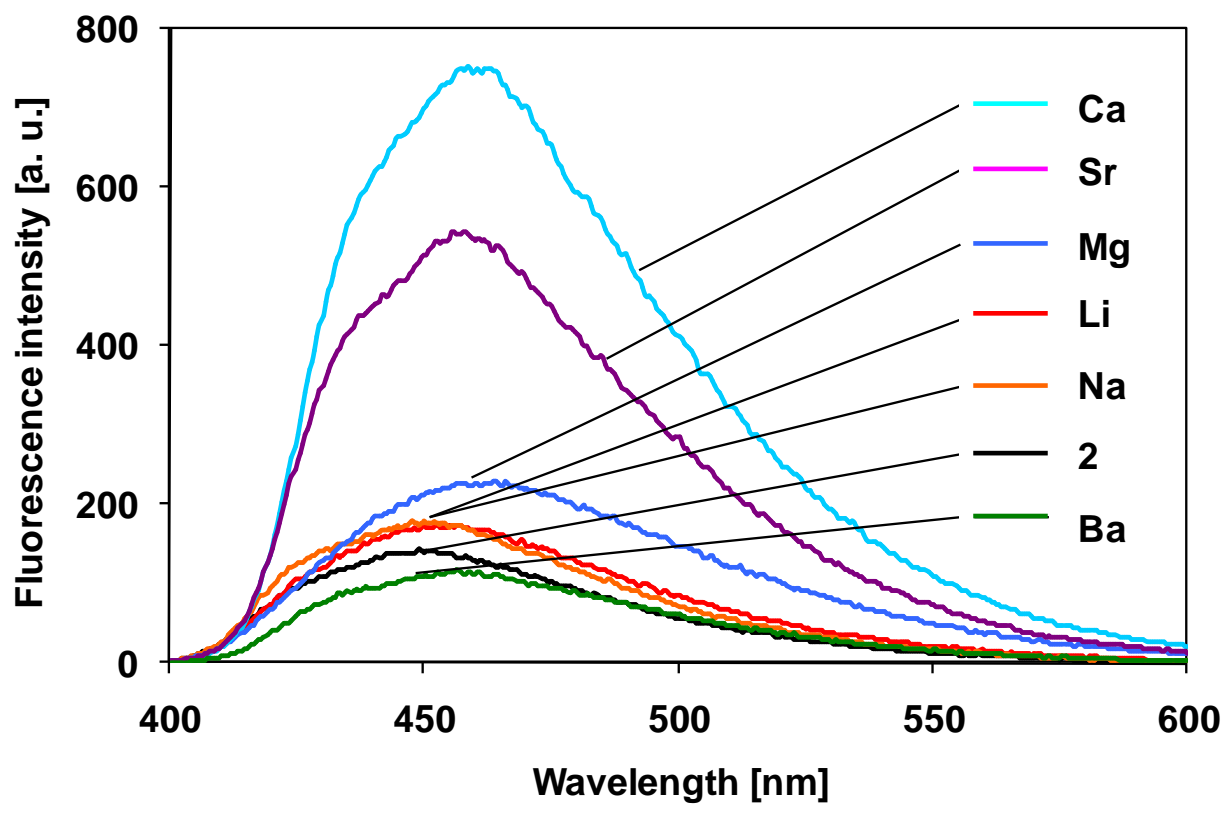


Fig. 3. Fluorescence spectra of 2 in the presence of metal ions. $[2]_{0}=1 \times 10^{-5} \mathrm{M}$,

$$
\left[\mathrm{Me}^{\mathrm{n}+}\right]_{0}=4 \times 10^{-5} \mathrm{M}, \lambda_{\mathrm{ex}}=380 \mathrm{~nm} .
$$

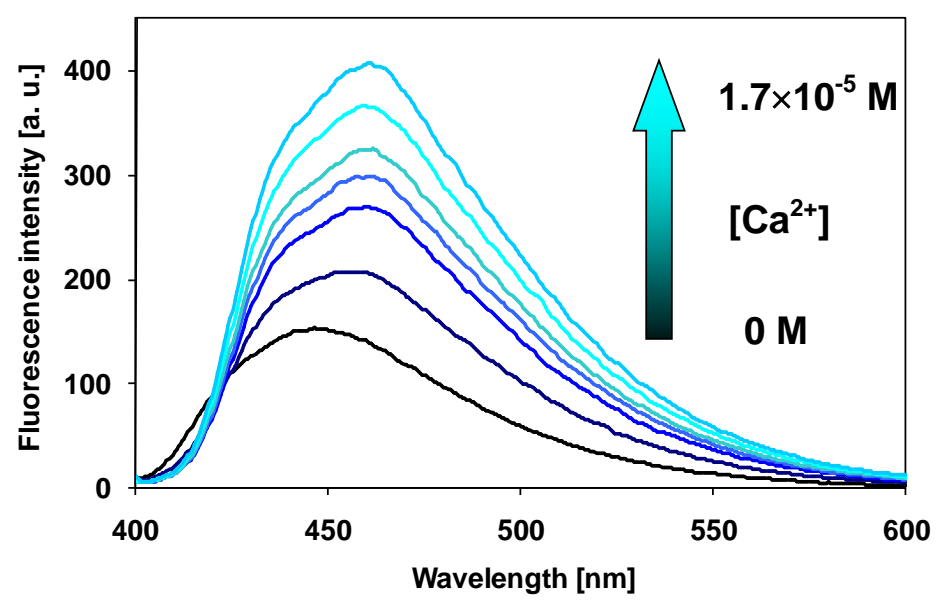

Fig. 4. Variation of the fluorescence spectrum of 2 upon the addition of $\mathrm{Ca}^{2+}$ ion.

$$
[2]_{0}=1 \times 10^{-6} \mathrm{M} \text {. }
$$

The 21-membered crown 2 was found a much more sensitive sensor for metal ions. Its visible absorption and fluorescence bands were also shifted to the red upon complexation, but, in contrast to $\mathbf{1}$, the metal binding by $\mathbf{2}$ was associated with significant fluorescence enhancement (see Figs. 3 and 4). It was established by the global fitting of the fluorescence spectra that the $\mathrm{Li}, \mathrm{Na}, \mathrm{Mg}, \mathrm{Ca}$ and $\mathrm{Sr}$ complexes of 2 had 1:1 stoichiometry, whereas the spectra of the mixtures of 2 with $\mathrm{BaClO}_{4}$ ions could be described in terms of the simultaneous

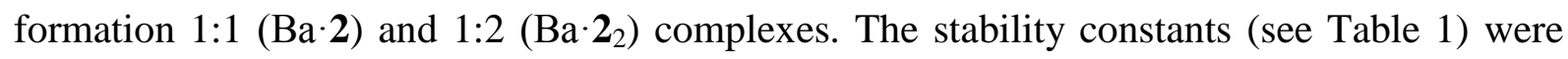
substantially higher for $\mathbf{2}$ than for $\mathbf{1}$, in particular in case of $\mathrm{Ca} \cdot \mathbf{2}$ and $\mathrm{Sr} \cdot \mathbf{2}$, where the $\mathrm{K}$ values were larger than $10^{6} \mathrm{M}^{-1}$.

\section{Enantiomer recognition}

The enantioselectivity of the two hosts was tested by comparing the spectral changes induced by the addition of the enantiomer pairs of the chiral ammonium salts (R)/(S)-PEA, (R)/(S)-NEA, (R)/(S)-PAMA and (R)/(S)-PGME (see Fig. 5). Ligand 1 showed only small changes in the presence of the amine guests, not allowing a quantitative evaluation. In contrast, the similar spectra of $\mathbf{2}$ showed distinct changes - red shifts of the lowest energy absorption and the fluorescence bands and a marked quenching of fluorescence as the concentration of the ammonium salt was increased (see Fig. 6). Besides, the calculated 
stability constants (see Table 2) proved a clear enantiodiscrimination in the case of all the four guest pairs, the highest selectivity was found in its reactions with PEA, where the ratio of the association constants was $\mathrm{K}((R)-\mathrm{PEA}) / \mathrm{K}((S)-\mathrm{PEA})>3$.

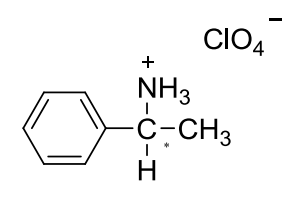

$(\mathrm{R}) /(\mathrm{S})-\mathrm{PEA}$

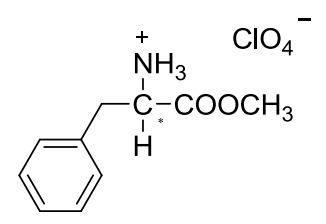

(R)/(S)-PAMA

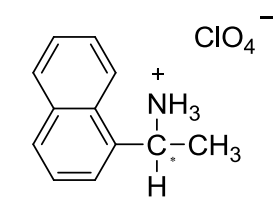

$(\mathrm{R}) /(\mathrm{S})-\mathrm{NEA}$

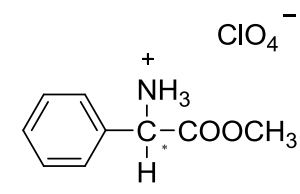

(R)/(S)-PGME

Fig. 5. Chiral ammonium salts used in the enantiomeric recognition studies. 

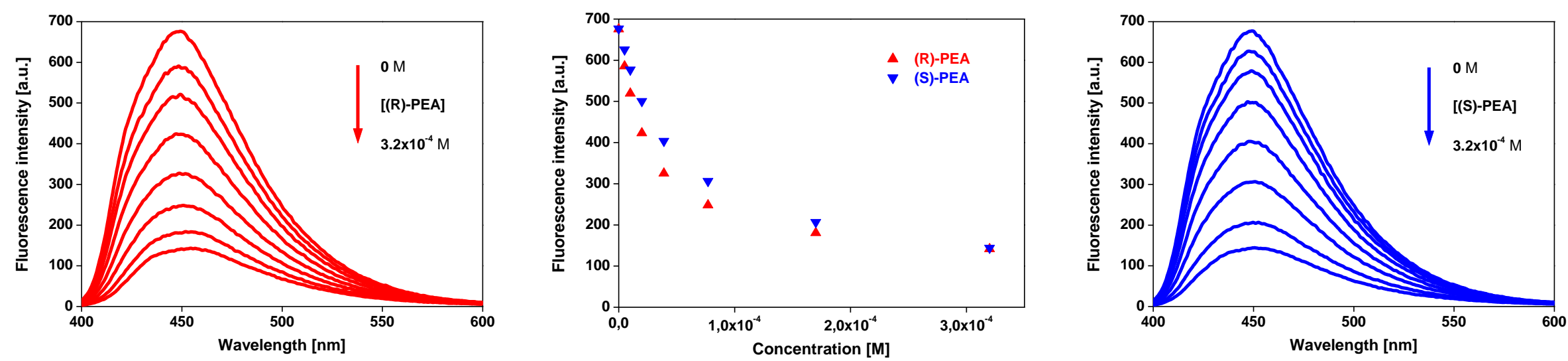

Fig. 6. Fluorescence spectra of 2 in the presence of $(R)$ - and $(S)$-PEA. $[2]_{0}=1 \times 10^{5} \mathrm{M}$. Plots of the fluorescence intensities at $\lambda_{\mathrm{em}}=450 \mathrm{~nm}$ vs. the concentrations of added $(R) /(S)$-PEA are shown in the middle box. 
Table 2. Stability constants for complexes of $\mathbf{2}$ with the enantiomers of chiral ammonium guests.

\begin{tabular}{lc}
\hline & $\begin{array}{c}\lg \mathrm{K} \\
\left(\mathrm{K} \mathrm{in}^{-1}\right)\end{array}$ \\
\hline (R)-PEA & $4.69 \pm 0,01$ \\
(S)-PEA & $4.27 \pm 0,02$ \\
(R)-NEA & $4.97 \pm 0,02$ \\
(S)-NEA & $4.69 \pm 0,02$ \\
(R)-PAMA & $4.85 \pm 0,06$ \\
(S)-PAMA & $4.73 \pm 0,04$ \\
(R)-PGME & $5.46 \pm 0,07$ \\
(S)-PGME & $5.38 \pm 0,02$ \\
\hline
\end{tabular}

The opposite changes of the fluorescence intensity of $\mathbf{2}$ enhancement in the presence of metal ions, reduction in the presence of ammonium ions is an interesting feature of this ligand and can be interpreted in terms of the different nature of the molecular interactions in the two types of complexes. A number of chemosensors have been reported consisting of an acridine signalling group, and a coordination sphere involving one or more amino or amide groups attached directly, or via one methylene group to the acridine ring. A few of these sensors have been found to show a spectacular fluorescent enhancement upon the binding of selected metal ions ${ }^{33-35}$ and amino acids. ${ }^{36}$ This 'turn-on' behavior is explained in terms of the suppression of a quenching mechanism in the complex, a photo-induced electron transfer ${ }^{37}$ (PET) that takes place from the amino (amide) nitrogen atom to the ring nitrogen in the free ligand. Such a PET effect can not be expected from 2, with the weaker electron donor oxygen atoms attached to the 2 and 9 positions of the acridine unit. Yet, the fluorescence enhancement as well as the red shift of the fluorescence band, induced by the metal ions are significant, in particular in case of $\mathrm{Ca}^{2+}$. These spectral changes are similar to the changes in the fluorescence spectrum of acridine upon protonation, ${ }^{38,39}$ and are presumably due to coordination of the metal ions by the aromatic nitrogen (besides the crown oxygens), which led to a considerable perturbation of the lowest electronic states of the acridine fluorophor. 
In contrast, the ammonium complexes of $\mathbf{2}$, held together by different type intermolecular forces (hydrogen bonds, $\pi-\pi$ stacking), showed fluorescence quenching.

A few ${ }^{1} \mathrm{H}$ NMR experiments (in $\mathrm{CDCl}_{3}, 500 \mathrm{MHz}$ ) were carried out to prove the complex formation and the enantioselectivity. Comparing the spectra of $(S)-\mathrm{PEA}^{*} \mathrm{HClO}_{4}$, crown ether 2, the complex of $(S)-\mathrm{PEA}^{*} \mathrm{HClO}_{4}$ with 2 (molar ratio 1:1) and the complex of $(R)-\mathrm{PEA}^{*} \mathrm{HClO}_{4}$ with 2 (molar ratio 1:1) one can say the following. In each complex of crown ether 2 , the ammonium cation proton signals of the PEA were shift from 6.50 to $8.40 \mathrm{ppm}(\Delta \delta$ $=1.90 \mathrm{ppm})$, whereas the $\mathrm{CH}_{3}$ proton signals in the complex of $(S)-\mathrm{PEA}^{*} \mathrm{HClO}_{4}$ with 2 underwent a significant upfield shift from $1.62 \mathrm{ppm}$ to $1.26 \mathrm{ppm}(\Delta \delta=0.36)$. The same methyl protons in the complex of $(R)-\mathrm{PEA}^{*} \mathrm{HClO}_{4}$ with 2 was shift significantly from 1.62 to $1.13 \mathrm{ppm}(\Delta \delta=0.49)$. Other changes in respect of chemical shifts could not be observed due to the overlap of the signals. It appears that the changes of the shifts of $\mathrm{CH}_{3}$ (PEA) signals in the ${ }^{1} \mathrm{H}$ NMR spectra of the complexes may be a suitable indicator for the enantioselectivity.

\section{CONCLUSION}

The glucose-based 21-membered crown ether (2) showed a promising performance as a chiral fluorescent sensor molecule, its chiral discrimination ability was similar to that of various other crown ethers with $\mathrm{C}$ or $\mathrm{P}$ stereogenic centers. ${ }^{40}$ Due to the incorporation of the rigid acridine unit in the crown ring, the stability values for the complexes of 2 with the ammonium ions were higher than most of the values reported for more flexible crowns. As another consequence of the higher rigidity of our acridino crowns, only the 21-membered crown complexed ammonium ions, the 15-membered analogue was not able to do so.

The enantioselectivity can be indicated in the ${ }^{1} \mathrm{H}$ NMR spectra of the complexes forming from $\mathrm{PEA}^{*} \mathrm{HClO}_{4}$ with crown ether 2.

\section{ACKNOWLEDGEMENT}

The above project was supported by the Hungarian Scientific Research Fund (Grants K 75098 and $\mathrm{K} 108752$ ). 


\section{REFERENCES}

1. $\mathrm{Pu}, \mathrm{L} .:$ Fluorescence of organic molecules in chiral recognition. Chem. Rev. 104, 16871716 (2004).

2. Kumar, A.P., Jin, D., Le, Y.I.: Recent development on spectroscopic methods for chiral analysis of enantiomeric compounds. Appl. Spectrosc. Rev. 44, 267-316 (2009)

3. Pu, L.: Enantioselective fluorescent sensors: A tale of BINOL. Accounts. Chem. Res. 45, 150-163 (2012)

4. Galán, A., Andreu, D., Echavarren, A.M., Prados, P., de Mendoza, J.: A receptor for the enantioselective recognition of phenylalanine and tryptophan under neutral conditions J. Am. Chem. Soc. 114, 1511-1512, (1992)

5. Webb, T.H., Wilcox, C.S.: Enantioselective and diastereoselective molecular recognition of neutral molecules. Chem. Soc. Rev. 22, 383-395 (1993)

6. Barboiu, M.D., Hovnanian, N.D., Luca, C., Cot, L.: Functionalized derivatives of benzocrown-ethers, V. Multiple molecular recognition of zwitterionic phenylalanine. Tetrahedron, 55, 9221-9232 (1999)

7. Kertész, J., Móczár, I., Kormos, A., Baranyai, P., Kubinyi, M., Tóth, K., Huszthy, P.: Synthesis and enantiomeric recognition studies of dialkyl-substituted 18-crown-6 ethers containing an acridine fluorophore unit. Tetrahedron:Asymmetr. 22, 684-689 (2011)

8. Móczár, I., Huszthy, P., Maidics, Z., Kádár, M., Tóth, K.: Synthesis and optical characterization of novel enantiopure BODIPY linked azacrown ethers as potential fluorescent chemosensors. Tetrahedron 65, 8250-8258 (2009)

9. Móczár, I., Huszthy, P., Mezei, A., Kádár, M., Nyitrai, J., Tóth, K.: Synthesis and optical characterization of novel enantiopure azacrown ethers containing an acridinone or an $\mathrm{N}$-methylacridinone unit as potential fluorescent chemosensors. Tetrahedron 66, $350-358$ (2010)

10. Luo, J., Zheng, Q.Y., Che,n C.F., Huang, Z.T.: Facile synthesis and optical resolution of inherently chiral fluorescent calix[4]crowns: enantioselective recognition towards chiral leucinol. Tetrahedron 61, 8517-8528 (2005)

11. Upadhyay, S.P., Pissurlenkar, R.R.S., Coutinho, E.C., Karnik, A.V.: Furo-fused BINOL based crown as a fluorescent chiral sensor for enantioselective recognition of phenylethylamine and ethyl esther of valine. J. Org. Chem. 72, 5709-5714 (2007)

12. Kim, K.S., Jun, E.J., Kim, S.K., Choi, H.J., Yoo, J., Lee, C.H., Hyun, M.H., Yoon, J.: Fluorescent studies of two new binaphthyl-azacrown-anthracene fluorophores with 
metal ions and chiral guests: dual fluorescent detection via binaphthyl and anthracene groups. Tetrahedron Lett. 48, 2481-2484 (2007)

13. Xu, K., Jiao, S., Yao, W., Xie, E., Tang, B., Wang, C.: Syntheses and highly enantioselective fluorescent recognition of $\alpha$-aminocarboxylic acid anions using chiral oxacalix[2] arene[2]bisbinaphthes. Chirality 24, 646-651 (2012)

14. Stoddart, J.F.: From carbohydrates to enzyme analogs. Chem. Soc. Rev. 8, 85-142 (1979)

15. Miethchen, R., Fehring, V.: Carbohydrate-based crown ethers containing 1,4-linked Dglucopyranose moieties. Synthesis 1851-1856 (1998)

16. Faltin, F., Fehring, V., Kadyrov, R., Arrieta, A., Schareina, T., Selke, R., Miethchen, R.: Synthesis of carbohydrate-based chiral crown ethers as ligands in asymmetric hydrogenation. Synthesis 638-646 (2001)

17. Faltin, F., Fehring, V., Miethchen, R.: Chiral crown ethers based on galactopyranosides. Synthesis 1851-1856 (2002)

18. Bakó, P., Töke, L.: Novel monoaza- and diazacrown ethers incorporating sugar units and their extraction ability towards picrate salts. J. Inclusion Phenom. 23, 195-201 (1995)

19. Bakó, P., Kiss, T., Tőke, L.: Chiral azacrown ethers derived from D-glucose as catalysts for enantioselective Michael addition. Tetrahedron Lett. 38, 7259-7262 (1997)

20. Bakó, P., Vízvárdi, K., Bajor, Z., Tőke L.: Synthesis and application in asymmetric synthesis of azacrown ethers derived from D-glucose. Chem. Commun. 1193-1194 (1998)

21. Bakó, P., Keglevich, G., Rapi, Z.: Asymmetric phase transfer reactions catalyzed by chiral crown ethers derived from monosaccharides. Lett. Org. Chem. 7, 645-656 (2010)

22. Bakó, P., Keglevich, G., Rapi, Z., Tőke, L.: The enantiomeric differentiation ability of chiral crown ethers based on carbohydrates. Curr. Org. Chem. 16, 297-304 (2012)

23. Huszthy, P., Oue, M., Bradshaw, J.S., Zhu, C.Y., Wang, T.M., Dalley, N.K., Curtis, J.C., Izatt, R.M.: New symmetrical chiral dibenzyl-substituted and diphenyl-substituted diamido-18-crown-6, dithionoamido-18-crown-6, diaza-18-crown-6, and azapyridino18-crown-6 ligands. J. Org. Chem. 57, 5383-5394 (1992)

24. Späth, A., König, B.: Molecular recognition of organic ammonium ions in solution using synthetic receptors. Beilstein J. Org. Chem. 6, No. 32. 1-111 (2010)

25. Huszthy, P., Samu, E., Vermes, B., Mezey-Vándor, G., Nógrádi, M., Bradshaw, J.S.: Synthesis of novel acridino- and phenazino-18-crown-6 ligands and their optically pure 
dimethyl-substituted analogues for molecular recognition studies. Tetrahedron 55, 14911504 (1999)

26. Kertész, J., Huszthy, P., Kormos, A., Bertha, F., Horváth, V., Horvai, G.: Synthesis of new optically active acridino-18-crown-6 ligands and studies of their potentiometric selectivity toward the enantiomers of protonated 1-phenylethylamine and metal ions. Tetrahedron:Asymmetr. 20, 2795-2801 (2009)

27. Lee, H.N., Kim, H.N., Swamy, K.M.K., Park, M.S., Kim, J., Lee, H., Lee, K.H., Park, S., Yoon, J.: New acridine derivatives bearing immobilized azacrown or azathiacrown ligands as fluorescent chemosensors for $\mathrm{Hg}(2+)$ and $\mathrm{Cd}(2+)$. Tetrahedron Lett. 49, $1261-1265$ (2008)

28. Kertész, J., Bognár, B., Kormos, A., Móczár, I., Baranyai, P., Kubinyi, M., Kálai, T., Hideg, K., Huszthy, P.: Synthesis and metal ion complexation of spin labeled 18-crown6 ethers containing an acridone or an acridine fluorophore unit. Tetrahedron 67, 8860$8864(2011)$

29. Ewins, A.J.: The constitution and synthesis of damascenine, the alkaloid of nigella damascena. J. Chem. Soc. 101, 544-552 (1912)

30. Ife, R.J., Brown, T.H., Blurton, P., Keeling, D.J., Leach, C.A., Meeson, M.L., Parsons, M.E., Theobald, C.J.: Reversible inhibitors of the gastric $(\mathrm{H}+\mathrm{K}+)$-ATPase. 5. Substituted 2,4-diaminoquinazolines and thienopyrimidines. J. Med. Chem. 38, 2763$2773(1995)$

31. Huszthy, P., Köntös, Z., Vermes, B., Pintér, Á.: Synthesis of novel fluorescent acridinoand thioacridino-18-crown-6 ligands. Tetrahedron 57, 4967-4975 (2001)

32. Makó, A., Bakó, P., Szöllősy, Á., Bakó, T., Peltz, C., Keglevich, P.: Synthesis of chiral pyridino-15-crown-5 type ligands containing $\alpha$-D-hexopyranoside unit and their application in asymmetric synthesis. ARKIVOC 165-179 (2009)

33. Wang, Y., Hu, X.Y., Wang, L., Shang, Z.B., Chao, J.B., Jin, W.J.: A new acridine derivative as a highly selective 'off-on' fluorescence chemosensor for $\mathrm{Cd}^{2+}$ in aqueous media. Sensor Actuat. B-Chem. 156, 126-131 (2011)

34. Karagöz, F., Güney, O., Kandaz, M., Bilgicli, A.T.: Acridine-derivated receptor for selective mercury binding based on chelation-enhanced fluorescence effect. J. Lumin. 132, 2736-2740 (2012)

35. Wang, Y., Shi, L.L., Sun, H.H.S., Shang, Z.B., Chao, J.B., Jin, W.J.: A new acridine derivative as a highly selective fluoroionophore for $\mathrm{Cu}^{2+}$ in $100 \%$ aqueous solution. $\mathrm{J}$. Lumin. 139, 16-21 (2013) 
36. Sirikulkajorrn, A., Duanglaor, P., Ruangpornvisuti, V., Tomapatanaget, B., Tuntulani, T.: Tryptophan receptors containing acridine-based thiourea. Supramol. Chem. 21, 486494 (2009)

37. De Silva, A.P., Gunaratne, H.Q.N., Gunnlaugsson, T., Huxley, A.J.M., McCoy, C.P., Rademacher, J.T., Rice, T.E.: Signaling recognition events with fluorescent sensors and switches Chem. Rev. 97, 1515-1566 (1997)

38. Rubio-Pons, O., Serrano-Andres, L., Merchan, M.: A theoretical insight into the photophysics of acridine. J. Phys. Chem. A 105, 9664-9673 (2001)

39. Samsonova, L.G., Selivanov, N.I., Kopylova, T.N., Artyukhov, V.Y., Maier, G.V., Plotnikov, V.G., Sazhnikov, V.A., Khlebunov, A.A., Alfimov, M.V.: Experimental and theoretical investigation of the spectral and luminescent properties of some acridine compounds. High Energ. Chem. 43, 105-115 (2009)

40. Izatt, R.M., Pawlak, K., Bradshaw, J.S., Brüning, R.L.: Thermodynamic and kinetic data for macrocycle interaction with cations, anions, and neutral molecules. Chem. Rev. 95, 2529-2586 (1995) 